\title{
La aceptación y la repudiación de herencias por las fundaciones
}

\author{
María Ángeles Fernández EgeA \\ Doctoranda en la Universidad del País Vasco / Euskal Herriko Unibertsitatea
}

DOI: $10.1387 /$ reves. 17535

Fecha de entrada: 30/11/2015

Fecha de aceptación: 11/02/2016

\begin{abstract}
Sumario: 1. Introducción. 2. Planteamiento general sobre la aceptación y repudiación hereditarias. 3. La aceptación de la herencia a beneficio de inventario por las fundaciones: elementos personales y elementos formales. 3.1. Elementos personales. a) Capacidad para suceder. b) Legítimos representantes de la fundación para llevar a cabo la aceptación o la repudiación de la herencia. 3.2. Requisitos formales. a) El beneficio legal de inventario a favor de las fundaciones. b) Tramitación notarial del inventario tras la Ley 15/2015, de 2 de julio, de la Jurisdicción Voluntaria. 4. La aceptación de legados con cargas. 5. La repudiación de la herencia: formalidades y requisitos complementarios de control. Bibliografía.
\end{abstract}

\section{Resumen:}

Las fundaciones, en tanto se encuentren válidamente constituidas y gocen de personalidad jurídica, pueden aceptar y repudiar herencias ajustándose a los requisitos establecidos en su normativa específica. Tanto la aceptación a beneficio de inventario por disposición de la ley como la exigencia de posterior comunicación al Protectorado de la repudiación de la herencia y de la aceptación de legados con cargas, pone de manifiesto la necesaria intervención pública en la gestión patrimonial de las fundaciones. Una intervención justificada por el interés general de los fines fundacionales, que ha tenido diferentes intensidades desde el artículo 993 del Código Civil, pasando por la normativa específica de fundaciones y hasta el reciente artículo 93 de la Ley 15/2015, de la Jurisdicción Voluntaria. Sin desconocer que el control administrativo debe subsistir en aquellos supuestos en que pueda tener lugar un deterioro del patrimonio de la fundación con el consiguiente quebranto de los fines fundacionales, la autonomía y libertad de los Patronos debe, no obstante, verse fortalecida.

\section{Palabras clave:}

Sucesión, aceptación, repudiación, herencia, Patronato, beneficio de inventario, Protectorado, comunicación. 


\begin{abstract}
:
Foundations, as are validly constituted and have legal personality, can accept and repudiate inheritances according to the requirements of their specific regulation. Both acceptance benefit of inventory provision of the law as requiring later communication to the Protectorate of the repudiation of inheritance and acceptance of legacies with loads show the necessary public intervention in the management of foundations heritage. Intervention justified by the general interest of the foundational purposes, which has had different intensities from article 993 of the Civil Code, to specific regulations foundations and to the recent article 93 of Law 15/2015, of Voluntary Jurisdiction. While recognizing that the administrative control must subsist in those situations where a deterioration of the patrimony of the foundation with the consequent breaking of the foundational purposes can take place, autonomy and freedom of the Patrons should, however, be strengthened.
\end{abstract}

\title{
Keywords:
}

Succession, acceptance, repudiation, inheritance, Patrons, benefit of inventory, Protectorate, communication.

Claves Econlit:

K110, K410

\section{Introducción}

El derecho de fundación para fines de interés general se encuentra reconocido en el artículo 34 de la Constitución española de 1978.

La Ley 30/1994, de 24 de noviembre, de Fundaciones y de incentivos fiscales a la participación privada en actividades de interés general, fue la primera ley española que reguló de forma general las fundaciones. Esta Ley fue sustituida por la hoy vigente Ley 50/2002, de 26 de diciembre, de Fundaciones, que, con la finalidad de desarrollar el derecho de fundación, regula las fundaciones de competencia estatal y establece las normas de régimen jurídico de las fundaciones que corresponde dictar al Estado.

La competencia en materia de fundaciones ha sido, no obstante, transferida a todas las Comunidades Autónomas, por lo que junto a las fundaciones estatales, existen fundaciones autonómicas que desarrollan principalmente sus actividades dentro del territorio de una determinada Comunidad Autónoma. Asumida esta competencia, la mayoría de las Comunidades Autónomas han dictado normativa específica al respecto. 
Así, junto a la referida Ley estatal, cabe destacar, por tanto, las siguientes leyes autonómicas.

En Cataluńa, la Ley 4/2008, de 24 de abril, del libro tercero del Código civil de Cataluña, relativo a las personas jurídicas, que, a su vez, ha sido objeto de cambios puntuales por medio de la Ley 7/2012, de 15 de junio, y la Ley 21/2014, de 29 de diciembre, del protectorado de las fundaciones y de verificación de la actividad de las asociaciones declaradas de utilidad pública; en Galicia, la Ley 12/2006, de 1 de diciembre, de fundaciones de interés gallego; Ley 12/1994, de 17 de junio, de Fundaciones del País Vasco; en las Islas Baleares, el Decreto 61/2007, de 18 de mayo, de Regulación del Registro Único de Fundaciones de la Comunidad Autónoma de las Illes Balears y de Organización del Ejercicio del Protectorado; en Aragón, por su parte, se ha promulgado el Decreto 276/1995 de 19 de diciembre de la Diputación general de Aragón por el que se regulan las competencias en materia de fundaciones y se crea el Registro de Fundaciones; finalmente, en Navarra, cabe destacar la Ley foral 10/1996 de 2 de julio reguladora del régimen tributario de las Fundaciones y de las Actividades de Patrocinio.

Han dictado también normativa específica las Comunidades de Madrid (Ley 1/1998, de 2 de marzo, de Fundaciones de la Comunidad de Madrid), Castilla y León (Ley 13/2002, de 15 de julio, de Fundaciones de Castilla y León), Canarias (Ley 2/1998, de 6 de abril, de Fundaciones Canarias), Andalucía (Ley 10/2005, de 31 de mayo, de Fundaciones de la Comunidad Autónoma de Andalucía), Valencia (Ley 8/1998, de 9 de diciembre, de fundaciones de la Comunidad Valenciana) y La Rioja (Ley 1/2007, de 12 de febrero, de Fundaciones de la Comunidad Autónoma de La Rioja).

La enumeración de la legislación autonómica se ha estructurado en dos grupos diferenciados, según haya sido dictada por Comunidades Autónomas con o sin competencia en materia de Derecho civil. Y la razón de esta distinción no pasa tanto porque la materia relativa a las fundaciones se entienda como derecho civil «foral o especial, allí donde exista» (ex art. 149.1.8. ${ }^{\circ} \mathrm{CE}$ ), sino que entendiendo que el derecho de fundación tiene un fundamento constitucional diferente (ex art. $34 \mathrm{CE}$ ), sin embargo va a enlazar en nuestro artículo con otra materia, la aceptación y repudiación de herencias, que, sin lugar a dudas, se integra dentro del Derecho civil.

El precepto que en la Ley 50/2002, de 26 de diciembre, de Fundaciones regula la aceptación y la repudiación de herencias, legados y donaciones es el número 22. Y la Disposición final primera de la propia Ley de Fundaciones establece, en su apartado 2, letra b), en cuanto al ámbito de aplicación del precepto, que el artículo 22.1 y 2, excepto el último 
inciso del párrafo 2, constituye legislación civil y es de aplicación general al amparo de lo previsto en el artículo 149.1.8 ${ }^{\text {a }}$ de la Constitución, sin perjuicio de la aplicabilidad preferente del derecho civil especial, allí donde exista. Por tanto, en las Comunidades Autónomas con derecho civil propio, aquel precepto será de aplicación supletoria. Pero en aquellas otras Autonomías que han dictado leyes de fundaciones sin tener competencia civil, la regulación que en las mismas se contenga referente a la aceptación y repudiación de herencias no puede oponerse a lo previsto en la ley estatal al respecto ${ }^{1}$.

Finalmente, el apartado 3 de la referida Disposición final primera dispone que el último inciso del párrafo 2 del artículo 22, en lo referente al ejercicio de las acciones de responsabilidad, constituye legislación procesal, competencia estatal exclusiva, y en consecuencia de aplicación general en toda España al amparo del artículo 149.1.6. ${ }^{a}$ de la Constitución.

\section{Planteamiento general sobre la aceptación y la repudiación de la herencia}

En nuestro ordenamiento jurídico, de tradición romana, el fallecimiento del causante no determina ipso iure la adquisición de la herencia. Para que esta adquisición sea efectiva es necesario que el heredero, bien instituido en testamento por la voluntad del testador, bien llamado por la ley y declarado formalmente como tal en la correspondiente acta de declaración de herederos, manifieste libremente su voluntad de aceptarla ${ }^{2}$.

Conforme al artículo 659 del Código Civil, «[l]a herencia comprende todos los bienes, derechos y obligaciones de una persona que no se extin-

1 De esta opinión es SANTOS MORÓN, María José, «El patrimonio de la fundación. Régimen de gestión patrimonial» (arts. 19 a 22 y 28), en Comentarios a las leyes de Fundaciones y de Mecenazgo (directores Santiago Muñoz Machado, Miguel Cruz Amorós y Rafael de Lorenzo García), Fundación ONCE, Madrid, Iustel, 2005, p. 328.

2 En este sentido se ha manifestado con rotunda claridad IRURZUN GOICOA afirmando que «[a]ntes de la aceptación, el nombrado, haya sido testado o intestado el tránsito sucesorio, sólo es un heredero en potencia (...) porque así como nadie puede oponerse o impedir que se le nombre heredero potencial de un causante si esto es lo que la ley establece, nadie tampoco puede exigir ni imponer a un nombrado que herede a otro si no fuere ésta su voluntad». IRURZUN GOICOA, Domingo, «Función del acta de notoriedad en el abintestato (Comentario a la inquietante Resolución de 19 de junio de 2013)», Revista Jurídica del Notariado, núm. 85, enero-marzo 2013, p. 88. 
gan por su muerte». La herencia se configura, por tanto, como una unidad integrada tanto por el activo como por el pasivo hereditarios ${ }^{3}$. Frente a los sistemas llamados anglosajones, en los que al fallecimiento de un individuo su patrimonio entra en una fase de liquidación tras la cual se hará entrega al heredero del remanente líquido que resulte, en nuestro ordenamiento jurídico el heredero se subroga en la posición ius del causante, tanto en la titularidad de los bienes como en la de sus deudas y obligaciones ${ }^{4}$.

Cuando un heredero es llamado a una herencia es posible que, atendidas las circunstancias personales y patrimoniales concurrentes, no albergue duda alguna sobre su intención, bien de aceptarla bien de repudiarla. Sin embargo, también es posible que las dudas empañen su decisión. El desconocimiento del patrimonio del causante o, incluso, las sospechas fundadas de que se trata de un patrimonio gravado por multitud de obligaciones, sitúan al llamado a una herencia en una posición incierta por la desconfianza que le genera subrogarse sin garantías en la total posición jurídica del causante.

Para ello, el ordenamiento jurídico le proporciona al heredero la opción de aceptar la herencia a beneficio de inventario, incluso en el caso de que el testador se lo haya prohibido 5 . Con origen en el Derecho romano, el beneficio de inventario fue introducido por Justiniano como recurso para permitir al heredero restringir su responsabilidad en la adquisición de herencias gravadas en exceso por deudas del causante, con la finalidad de evi-

3 Puede verse en cuanto a la concepción romana de la herencia como universitas, ROCASASTRE MUNCUNILL, Luis, Derecho de Sucesiones, Tomo I, 2a edición, Barcelona, Editorial Bosch, 1995, pp. 33-35 y LACRUZ BERDEJO, José Luis, Tratado teórico práctico de Derecho Civil, Derecho de Sucesiones, Parte General, Tomo V, Vol. 1.', Barcelona, Bosch, 1961, pp. 36-38. En cuanto a los diferentes sistemas de organización del Derecho sucesorio, véase RIVAS MARTÍNEZ, Juan José, Derecho de sucesiones: común y foral, Tomo III, 4a edición, Madrid, Dykinson, 2009, pp. 2481.

${ }^{4}$ Cfr. arts. 659 y 661 Código Civil y art. 322 Código del Derecho Foral de Aragón.

5 Cfr. art. 1010 Código Civil y art. 461-14 Código civil de Cataluña. Existen, sin embargo, supuestos en que esta regla general no surte efectos y la ley impide al heredero aceptar la herencia a beneficio de inventario. Así, en el caso del art. 1002 Código Civil cuando afirma que "[l]os herederos que hayan sustraído u ocultado algunos efectos de la herencia pierden la facultad de renunciarla y quedan con el carácter de herederos puros y simples, sin perjuicio de las penas en que hayan podido incurrir»; o en el supuesto previsto en el párrafo 2 del art. 1019 Código Civil, modificado por la Ley 15/2015, de 2 de julio, de la Jurisdicción Voluntaria, cuando el heredero que se hubiese reservado el derecho de deliberar, deje de manifestar antes al Juzgado y ahora al Notario, dentro de treinta días contados desde el siguiente al en que se hubiere concluido el inventario, si acepta o repudia la herencia, en cuyo caso, se entenderá que la acepta pura y simplemente. 
tar la renuncia de las mismas ${ }^{6}$. El beneficio de inventario es, por tanto, la facultad que la ley pone a disposición del heredero para reducir su responsabilidad hereditaria de modo que, antes o después de aceptar la herencia, opta por mantenerla separada de sus bienes propios hasta que resulten pagados los acreedores conocidos y los legatarios ${ }^{7}$.

A diferencia de los efectos de la aceptación pura y simple en virtud de la cual quedará el heredero responsable de todas las cargas de la herencia ${ }^{8}$, no sólo con los bienes de ésta sino también con los suyos propios, si el heredero acude al recurso del beneficio de inventario, la responsabilidad ultra vires hereditatis ${ }^{9}$ queda limitada y se torna en responsabilidad intra vires hereditatis ${ }^{10}$ : el heredero se subroga en la posición jurídica activa y pasiva

${ }^{6}$ Siguiendo a CASTÁN TOBEÑAS podemos afirmar, que la institución del beneficio de inventario tiene su origen en Derecho romano «donde por consecuencia de la confusión de patrimonios producida por la sucesión universal, el heredero estaba obligado a responder de las deudas del difunto aun con sus propios bienes, y sólo acudiendo al remedio de la restitutio in integrum — que suponía causas graves y excepcionales, justificando o excusando el error del heredero al aceptar la herencia y que se concedía muy difícilmente- podía el heredero que había aceptado reparar el daño producido por la aceptación». Como nos recuerda el autor, fue Gordiano quien, para corregir estos efectos, primero concedió a los militares el privilegio de no responder de las deudas sino hasta donde llegaran los bienes hereditarios. Y Justiniano, en una Constitución del ańo 531 (Codex 22, 6,30), generalizó el beneficio a todos los herederos que al aceptar la herencia declarasen que lo hacían conforme a un determinado inventario. CASTÁN TOBEÑAS, José, Derecho civil español, común y foral. Derecho de sucesiones. La sucesión en general. La sucesión testamentaria (1 a parte), Tomo VI, Vol.I, 9a edición, Madrid, Reus, 1989, p. 168.

7 Cfr. art. 1023 y 1026 Código Civil y art. 461-20 Código civil de Cataluña.

8 Cfr. arts. 1003 y 1023 (a contrario sensu) Código Civil y art. 461-18 Código civil de Cataluña.

9 En cuanto a la consideración de la responsabilidad ultra vires como regla general en nuestro Código Civil y las numerosas cuestiones que plantea el beneficio de inventario, hace notar CASTÁN TOBEÑAS cómo algunos sectores doctrinales se vienen planteando la duda de si no sería más adecuado a la configuración actual de la herencia, a la par que más sencillo, limitar por ley, sin necesidad de inventario, la responsabilidad del heredero, de manera que nunca pudiera éste verse perjudicado por la herencia, optando como regla general por un sistema de responsabilidad intra vires hereditatis. Como recuerda el autor, así lo establecen las legislaciones de tradición más germánica que romana y que siguió el Derecho aragonés anticipándose a las legislaciones y tendencias modernas. Y concluye que, a su juicio, para implantar este sistema sería necesario hacerlo con precaución y completarlo con «las adecuadas garantías a favor de los acreedores y de los legatarios, ya sean dichas garantías de tipo civil o más bien procesal.» CASTÁN TOBEÑAS, J., Derecho civil español..., Tomo VI, Vol.I, cit., pp. 163-167. En nuestro ordenamiento jurídico apuestan por la limitación de responsabilidad el Derecho navarro (cfr. ley 318 Compilación de Derecho Civil Foral de Navarra), el aragonés (cfr. art. 355 Código del Derecho Foral de Aragón) y el vasco (cfr. art. 21.2 Ley de Derecho Civil Vasco).

${ }^{10}$ La doctrina se ha planteado si supuesta la responsabilidad intra vires hereditatis del heredero que acepta la herencia a beneficio de inventario, esta responsabilidad es cum viribus o 
del causante, no sólo en sus bienes y derechos, sino también en sus deudas, pero sólo responderá de ellas con los bienes propios de la herencia, no con los suyos propios. De igual modo, la confusión de patrimonios que rige como regla general en nuestro ordenamiento jurídico desaparece, al tiempo que el heredero que acepta a beneficio de inventario conserva contra el caudal hereditario todos los derechos y acciones que tuviera contra el difunto ${ }^{11}$.

\section{La aceptación de la herencia a beneficio de inventario por las fundaciones: elementos personales y elementos formales}

\subsection{Elementos personales}

El Código Civil contiene una regla general sobre la capacidad para aceptar y repudiar herencias en el apartado primero de su artículo 992 conforme al cual:

pro viribus, esto es, si responde con los mismos bienes de la herencia o por el valor de los mismos bienes de la herencia. ROCA-SASTRE MUNCUNILL afirma que «[e]n la doctrina casi unánimemente y en la jurisprudencia (...) prevalece la solución de que el heredero responde con los mismos bienes hereditarios; (...) las bases de esta solución radican: en el propio artículo 1023, que en su número 3 dispone que no se confunden para ningún efecto, en daño del heredero, sus bienes particulares con los que pertenezcan a la herencia, de suerte que tal responsabilidad es de concreción, no de limitación o pro viribus, ya que en ésta se produce la correspondiente confusión de patrimonios; de los artículos 1003, sensu contrario, 1029, 1031,1032 y 1034 , que (...) se refieren siempre a los bienes hereditarios o al remanente de la herencia; y de la no exigencia de la valoración de los bienes de la herencia». ROCA-SASTRE MUNCUNILL, Luis, Derecho de Sucesiones, Tomo III, $1^{\text {a }}$ edición, Barcelona, Editorial Bosch, 1994. pp. 505-506. En este mismo sentido se expresa RIVAS MARTÍNEZ, cuando afirma que " $[s]$ on exclusivamente los bienes relictos en los que se concreta la responsabilidad del heredero beneficiario, y ello porque nuestro sistema es el de responsabilidad cum viribus hereditatis, por ende, no responderán los bienes propios del heredero ya que éste sólo viene obligado propter rem, por lo que recibe y con lo que recibe, pero no personalmente». RIVAS MARTÍNEZ, J.J., Derecho de sucesiones..., Tomo III, cit., p. 2520.

Sin embargo, el art. 21.2 de la Ley de Derecho Civil Vasco claramente establece la responsabilidad pro viribus cuando dispone que el heredero responde de las obligaciones del causante, de los legados y de las cargas hereditarias hasta el valor de los bienes heredados en el momento de la delación.

11 Como dice ROCA-SASTRE MUNCUNILL, a pesar de que el art. 1023.2 Código Civil se refiera sólo a los derechos y acciones que el heredero tenga contra el difunto, se entiende que, al no haber confusión de patrimonios, «entran en el mismo [apartado 2] también los derechos y acciones que la herencia tenga contra el heredero». ROCA-SASTRE MUNCUNILL, L., Derecho..., Tomo III, cit., p. 506. 
"Pueden aceptar o repudiar una herencia todos los que tienen la libre disposición de sus bienes».

Junto a esta regla general, se contienen en los artículos siguientes una serie de reglas especiales en función de quién o quiénes sean los llamados a ser herederos. Entre estas reglas especiales, el artículo 993 se refiere a las herencias dejadas a las asociaciones, corporaciones y fundaciones y dispone expresamente:

"Los legitimos representantes de las asociaciones, corporaciones y fundaciones capaces de adquirir podrán aceptar la herencia que a las mismas se dejare; mas para repudiarla necesitan la aprobación judicial, con audiencia del Ministerio público».

Esta norma debe conectarse, en sede de fundaciones, con la contenida en el anteriormente referido artículo 22 de la Ley 50/2002, de 26 de diciembre, de Fundaciones que, por su parte, dispone:

"1. La aceptación de herencias por las fundaciones se entenderá hecha siempre a beneficio de inventario. Los patronos serán responsables frente la fundación de la pérdida del beneficio de inventario por los actos a que se refiere el artículo 1024 del Código Civil.

2. La aceptación de legados con cargas o donaciones onerosas o remuneratorias y la repudiación de las herencias, donaciones o legados sin cargas será comunicada por el Patronato al Protectorado en el plazo máximo de los diez dias hábiles siguientes, pudiendo éste ejercer las acciones de responsabilidad que correspondan contra los patronos, si los actos del Patronato fueran lesivos para la fundación, en los términos previstos en el esta Ley» ${ }^{12}$.

Tratándose de fundaciones, y al ser éstas organizaciones constituidas sin fin de lucro que tienen afectado de modo duradero su patrimonio a la realización de fines de interés general, el fundamento de estas normas pasa por entender que los poderes públicos deben ejercer cierto control a fin de

12 La Ley 30/1994, de 24 de noviembre, regulaba esta materia del siguiente modo en su artículo 20 (Herencias y Donaciones): "1. La aceptación de herencias por las fundaciones se entenderá hecha siempre a beneficio de inventario. 2. La aceptación de legados o donaciones con cargas que puedan desnaturalizar el fin fundacional requerirá la previa autorización del Protectorado. 3. No se podrán repudiar herencias o legados ni dejar de aceptar donaciones sin la previa autorización del Protectorado o, en defecto de éste, sin la aprobación judicial con audiencia del Ministerio Público». 
asegurar que los representantes de la fundación gestionan y disponen de su patrimonio sin desvirtuar este fin superior ${ }^{13}$.

\section{a) CAPACIDAD PARA SUCEDER}

Tal como dispone el artículo 993 del Código Civil, las fundaciones capaces de adquirir podrán aceptar las herencias que a las mismas se dejare.

Una fundación tendrá personalidad jurídica y será capaz de adquirir, conforme al artículo 35 del Código Civil, desde el instante mismo en que, con arreglo a derecho, hubiese quedado válidamente constituida. Lo mismo resulta a sensu contrario del artículo 745.2. ${ }^{\circ}$ del Código Civil, ya que cuando afirma que "[s]on incapaces de suceder: (...) las asociaciones o corporaciones no permitidas por la ley», está dando a entender que todas aquellas que sí estén permitidas por cumplir todos los requisitos y formalidades exigidas por la ley tendrán capacidad para suceder ${ }^{14}$.

Para saber, por tanto, cuándo las fundaciones han quedado válidamente constituidas, hay que acudir a su normativa específica. El artículo 4 de la Ley 50/2002, al igual que en su momento dispuso el artículo 3 de la Ley 30/1994, establece que las fundaciones tendrán personalidad jurídica desde la inscripción de la escritura pública de su constitución en el correspondiente Registro de Fundaciones, bien estatal, bien autonómico, según corresponda a su ámbito territorial de actividad. La inscripción, de carácter constitutivo, sólo podrá ser denegada cuando dicha escritura no se ajuste a las prescripciones de la Ley ${ }^{15}$.

13 En este sentido, afirma COBO GÁLVEZ en cuanto a la justificación del antiguo artículo 20 de la Ley 30/1994 que ésta «se encuentra en la concepción del legislador (...) de que la fundación ha de ser objeto de tutela no sólo por parte del Protectorado para garantizar el interés general, sino también mediante preceptos específicos, como el que comentamos, que pretenden la seguridad patrimonial de la fundación incluso frente a los propios donantes o administradores». COBO GÁLVEZ, Pablo. "Comentario al artículo 20 de la Ley de Fundaciones», en Comentarios a la Ley de Fundaciones e Incentivos Fiscales, Madrid, Marcial Pons, 1995, pp. 170-171.

14 Véase en este sentido GETE-ALONSO Y CALERA, Ma del Carmen, "Comentario al artículo 993", Código Civil comentado, Vol. II, Libro III, De los diferentes modos de adquirir la propiedad (artículos 609 a 1087), Cizur Menor, Navarra, Civitas Thomson Reuters, 2011, p. 1487.

15 Como nos recuerda GONZÁLEZ CUETO, «para que el encargado del Registro pueda proceder a inscribir la escritura debe calificar la misma y concluir que se ajusta a las prescripciones legales; (...) debe constatar también que existe el informe previo favorable del Protectorado sobre la idoneidad de los fines y sobre la suficiencia dotacional de la fundación que se pretenda constituir», conforme al art. 35.1 a) de la Ley de Fundaciones. GONZÁLEZ CUETO, Tomás, Comentarios a la Ley de Fundaciones: Ley 50/2002, de 26 de diciembre, Cizur Menor, Navarra, Aranzadi, 2003, p. 68. 
La fundación podrá constituirse por actos inter vivos o mortis causa. La constitución de la fundación por acto inter vivos se realizará mediante escritura pública con el contenido establecido en el artículo 10 de la Ley 50/2002. La constitución de la fundación por acto mortis causa se realizará testamentariamente, cumpliéndose en el testamento los requisitos establecidos para la escritura de constitución. Si en la constitución de una fundación por acto mortis causa el testador se hubiera limitado a establecer su voluntad de crear una fundación y de disponer de los bienes y derechos de la dotación, la escritura pública en la que se contengan los demás requisitos exigidos por esta Ley se otorgará por el albacea testamentario y, en su defecto, por los herederos testamentarios. En caso de que éstos no existieran, o incumplieran esta obligación, la escritura se otorgará por el Protectorado, previa autorización judicial ${ }^{16}$.

Otorgada la escritura fundacional, y hasta que tenga lugar la inscripción en el correspondiente Registro de Fundaciones, el Patronato de la fundación en formación realizará, además de los actos necesarios para la inscripción, únicamente aquellos otros que resulten indispensables para la conservación de su patrimonio y los que no admitan demora sin perjuicio para la fundación, los cuales se entenderán automáticamente asumidos por ésta cuando obtenga personalidad jurídica ${ }^{17}$. Por tanto, aunque es posible que se instituya heredera o legataria a una fundación en formación, cuando aún no esté válidamente constituida, lo cierto es que este llamamiento sólo tendrá eficacia si la fundación llega efectivamente a existir ${ }^{18}$.

\section{b) Legítimos REPRESENTANTES DE LA FUNDACIÓN PARA LLEVAR A CABO LA ACEPTACIÓN O LA REPUDIACIÓN DE LA HERENCIA}

Las fundaciones, como todas las personas jurídicas en general, necesitan de determinados órganos a través de los cuales poder manifestar su voluntad y desarrollar sus actividades y, de este modo, hacer efectiva la aceptación o repudiación hereditarias.

El legítimo representante de la fundación, conforme al artículo 14 de la Ley 50/2002, es el Patronato ${ }^{19}$. Este órgano de gobierno y representación, que deberá existir en toda fundación, adoptará sus acuerdos por mayoría en los términos establecidos en los estatutos. Estará constituido

16 Cfr. art. 9 Ley 50/2002, de 26 de diciembre, de Fundaciones.

17 Cfr. art. 13 Ley 50/2002, de 26 de diciembre, de Fundaciones.

18 Cfr. arts. 38 y 746 Código Civil.

19 Dentro del capítulo III de la Ley (arts. 15-18), del Gobierno de la Fundación, se regula la composición del Patronato, delegación y apoderamientos, responsabilidad de los patronos y sustitución, cese y suspensión de los mismos. 
por un mínimo de tres miembros, personas físicas o personas jurídicas, que elegirán entre ellos a un Presidente, si no estuviera prevista de otro modo la designación del mismo en la escritura de constitución o en los estatutos.

Sin perjuicio de las delegaciones y apoderamientos permitidos por la Ley, corresponde al Patronato cumplir los fines fundacionales y administrar con diligencia los bienes y derechos que integran el patrimonio de la fundación, manteniendo el rendimiento y utilidad de los mismos. Será, en consecuencia, el órgano legitimado y encargado de cumplir todos los requisitos legalmente previstos para aceptar o repudiar herencias, dentro de los fines más generales que se le encomiendan en la Ley. A pesar de las amplias facultades conferidas al Patronato, en determinados casos, como tendremos ocasión de examinar, su actuación va a quedar sometida al control previo o posterior del Protectorado.

\subsection{Requisitos formales}

a) El BENEFicio LEgAL DE INVENTARIO A FAVOR DE LAS FUNDACIONES

En el régimen del Código Civil, los requisitos exigidos, con carácter general, para poder disfrutar del beneficio de inventario son fundamentalmente dos: la manifestación, de forma expresa y solemne, de la decisión del heredero de acogerse al beneficio, conforme al artículo 1011; y la formalización de un inventario fiel y exacto del activo y del pasivo de la herencia, hecho en la forma y dentro los plazos previstos en los artículos 1013 a 1017 del mismo Código Civil ${ }^{20}$.

El beneficio de inventario que normalmente tendrá lugar, por tanto, por voluntad expresa del heredero, puede, no obstante, también desplegar sus efectos por disposición de la Ley. Junto a los diversos supuestos previstos en el Código Civil21 ${ }^{21}$ como la aceptación de la herencia por el

20 Frente a este modelo del Código Civil, en el Derecho catalán se facilita la opción por el beneficio de inventario flexibilizando el formalismo, tanto en la emisión de la voluntad, como en la formalización del inventario. En este sentido, GETE-ALONSO Y CALERA, Ma del Carmen, «Responsabilidad hereditaria», Tratado de derecho de sucesiones: Código civil y normativa civil autonómica: Aragón, Baleares, Cataluña, Galicia, Navarra, País Vasco, coordinado por Judith Solé Resina; María del Carmen Gete-Alonso y Calera (dir.), Tomo. 1, Cizur Menor, Navarra, Civitas Thomson Reuters, 2011, pp. 345 y 353.

21 Podemos señalar, sin ánimo exhaustivo, dentro del Código Civil los siguientes supuestos: - conforme al art. 957, que ha recibido nueva redacción en la Ley 15/2015, de 2 de julio, de la Jurisdicción Voluntaria, la aceptación de la herencia por el Estado, cuando éste sea llamado como heredero intestado por falta de parientes del testador, se entenderá 
Estado, la aceptación de la herencia que se deja a los pobres o los supuestos de aceptación a beneficio de inventario en sede de patria potestad o tutela, destaca, en especial, la aceptación de las herencias deferidas a favor de fundaciones que, conforme al artículo 22 de la Ley 50/2002, al igual que previamente ya había establecido el artículo 20 de la Ley 30/1994, se entenderá aceptada, como hemos visto, a beneficio de inventario.

Por tanto, a pesar de que el Código Civil no contiene mención expresa al efecto, lo cierto es que la normativa específica de fundaciones siempre ha optado por esta forma de aceptación a beneficio de inventario ${ }^{22}, \mathrm{y}$

siempre hecha a beneficio de inventario, sin necesidad de declaración alguna sobre ello; la herencia que se deja a los pobres, conforme al art. 992.2 se entenderá aceptada a beneficio de inventario; en sede de patria potestad, el supuesto del art. 166.2 del Código Civil, conforme al cual los padres deberán recabar autorización judicial para repudiar la herencia o legado deferidos al hijo y si el Juez denegase la autorización, la herencia sólo podrá ser aceptada a beneficio de inventario; en sede de tutela, el art. 272.1 dispone que el Juez necesitará autorización judicial para aceptar la herencia pura y simplemente, por lo que, $a$ contrario sensu, entendemos que, si falta la autorización, la herencia se entenderá aceptada a beneficio de inventario; finalmente, el caso previsto en el art. 1021 del mismo Código Civil: «El que reclame judicialmente una herencia de que otro se halle en posesión por más de un año, si venciere en el juicio, no tendrá obligación de hacer inventario para gozar de este beneficio, y sólo responderá de las cargas de la herencia con los bienes que le sean entregados».

Conforme al art. 461-16 Código civil de Cataluña, que regula el beneficio legal de inventario en Cataluña, disfrutan de pleno derecho del beneficio de inventario, aunque no lo hayan tomado, los herederos menores de edad, tanto si están emancipados como si no lo están, las personas puestas en tutela o curaduría, los herederos de confianza, las personas jurídicas de derecho público, y las fundaciones y asociaciones declaradas de utilidad pública o de interés social. También disfrutan del mismo las herencias destinadas a finalidades de interés general. Conforme al art. 117 Ley de Derecho Civil Vasco, la herencia a favor de las Administraciones Públicas se entenderá siempre aceptada a beneficio de inventario, sin necesidad de declaración alguna sobre ello; y el art. 139 del mismo Cuerpo legal dispone que durante la vigencia de la comunicación foral, el cónyuge llamado a una herencia no podrá repudiarla sin el consentimiento del otro y que a falta de acuerdo, se entenderá aceptada a beneficio de inventario. Finalmente, según el art. 268 Ley de Derecho Civil de Galicia, en los casos en que correspondiera heredar a la Comunidad Autónoma de Galicia la herencia se entenderá aceptada siempre a beneficio de inventario.

${ }^{22}$ A este respecto, nos recuerda MARÍN GARCÍA DE LONARDO cómo el artículo 27 del Decreto de Fundaciones Culturales de 1972 «estableció que las fundaciones podían aceptar herencias y legados sin necesidad de autorización previa del Protectorado, siempre que lo hicieran a beneficio de inventario. Cabía también la posibilidad de que se aceptase sin beneficio de inventario, siempre que se requiriese previamente una autorización expresa del Protectorado. A tal fin, debía acompañarse justificación suficiente de los motivos que le pudieran permitir a la Fundación renunciar al beneficio de inventario. En el caso de la aceptación de donaciones y legados con carga también era necesaria la previa 
esta misma línea ha sido la mantenida por la normativa autonómica en materia de fundaciones con carácter general. Así, establecen de forma expresa la aceptación de la herencia a beneficio de inventario en sede de fundaciones las Leyes de Cataluña ${ }^{23}$, Galicia ${ }^{24}$, Canarias ${ }^{25}$, Valen$\mathrm{cia}^{26}$, Andalucía ${ }^{27}$ y La Rioja ${ }^{28}$. Por el contrario, las leyes específicas de fundaciones de las Comunidades de Madrid, Castilla León o el País Vasco no contienen norma alguna que obligue a que la aceptación de las herencias por las fundaciones deba entenderse a beneficio de inventario. No obstante, teniendo en cuenta que la Ley estatal es aplicable tanto en Madrid como en Castilla León, por tener el artículo 22.1 de la Ley de Fundaciones el carácter de legislación civil, como se dijo anteriormente, en estas Comunidades se entenderá hecha de esta forma la aceptación hereditaria.

La doctrina española viene señalando de forma mayoritaria la conveniencia de la aceptación de la herencia por las fundaciones a beneficio de inventario $^{29}$. En efecto, la limitación de responsabilidad de la fundaciónheredera frente a las deudas y obligaciones del causante y la consiguiente conservación del patrimonio fundacional asegurando su integridad al no confundirse para ningún efecto con el patrimonio hereditario, son finalidades generales del beneficio de inventario que gozan de una especial signifi-

autorización del Protectorado, [que] debía concederse si se justificaba que las rentas y los frutos de los bienes donados o legados eran suficientes para atender la carga de que se tratase». MARÍN GARCÍA DE LONARDO, Teresa, "Comentario al artículo 22», Comentarios a la Ley de Fundaciones, coor. Jesús Olavarría Iglesia, Valencia, Tirant lo Blanch, 2008, pp. 593-594.

${ }^{23}$ El art. 461-16 del Código civil de Cataluńa, que regula el beneficio legal de inventario, establece que disfrutan de pleno derecho del beneficio de inventario, aunque no lo hayan tomado, junto a otras personas como los herederos menores de edad, tanto si están emancipados como si no lo están, las personas puestas en tutela o curaduría, los herederos de confianza o las personas jurídicas de derecho público, las fundaciones y asociaciones declaradas de utilidad pública o de interés social.

${ }^{24}$ Art. 30 Ley 12/2006, de 1 de diciembre, de fundaciones de interés gallego.

25 Art. 14.1 Ley 2/1998, de 6 de abril, de Fundaciones Canarias.

26 Art. 22.6 de la Ley 8/1998, de 9 de diciembre, de la Generalidad Valenciana, de fundaciones de la Comunidad Valenciana, según redacción dada por la Ley 9/2008, 3 julio, de la Generalitat.

27 Art. 29 Ley 10/2005, de 31 de mayo, de Fundaciones de la Comunidad Autónoma de Andalucía.

28 Art. 28 Ley 1/2007, de 12 de febrero, de Fundaciones de la Comunidad Autónoma de La Rioja.

29 Por todos ellos, véase GITRAMA GONZÁLEZ, Manuel, Comentarios al Código civil y Compilaciones forales, Tomo 14, Volumen I, Madrid, 1989, p. 129, citado por MARÍN GARCÍA DE LONARDO, T., «Comentario al artículo 22»..., cit., pp. 596-597. 
cación y trascendencia práctica cuando el llamado a heredar es una fundación, como persona jurídica de interés general ${ }^{30}$.

Como novedad introducida por el artículo 22 de la Ley de Fundaciones en este punto, se ańade un segundo párrafo a su apartado 1 y establece que "[l]os patronos serán responsables frente la fundación de la pérdida del beneficio de inventario por los actos a que se refiere el artículo 1024 del Código Civil».

Este párrafo nos conecta directamente con la cuestión de si el beneficio legal de inventario implica, en este caso, una aplicación automática del mismo, que exime ope legis de cumplimentar requisito alguno al efecto o si, por el contrario, nos encontramos ante una limitación a la autonomía del Patronato en el sentido de no permitir la aceptación pura y simple sino de abocar al órgano de representación de la fundación a aceptar la herencia a beneficio de inventario, pero exigiéndoles, al igual que en los supuestos de beneficio de inventario libremente elegido por el heredero, el cumplimiento de los requisitos de tiempo y forma legalmente previstos al efecto. Lo que la ley supliría en estos casos, sería la declaración o manifestación expresa de voluntad de acogerse a este beneficio $^{31}$, pero no la formación del inventario, que, tras la Ley 15/2015, de 2 de julio, de la Jurisdicción Voluntaria se tramitará ante Notario.

En Cataluña, el artículo 461-16 de la Ley 10/2008, de 10 de julio, del libro cuarto del Código civil de Cataluña, relativo a las sucesiones, que regula el beneficio legal de inventario, dispone expresamente que disfrutan de pleno derecho del beneficio de inventario, aunque no lo hayan tomado, entre otras

30 En cuanto a la justificación del beneficio de inventario en la aceptación de herencias deferidas a favor de fundaciones, puede verse MARÍN GARCÍA DE LONARDO, T., "Comentario al artículo 22»..., cit., pp. 596-597, quien entiende que «se trata de una medida que comparte su fundamento con el artículo 24 de la Ley de Fundaciones (...) tratando de salvaguardar la indemnidad del patrimonio fundacional y evitando su confusión con el patrimonio hereditario». LÓPEZ NIETO Y MALLO, por su parte, opina que con el beneficio de inventario se persigue garantizar la seguridad patrimonial de la fundación «incluso frente a los propios donantes y administradores». LÓPEZ NIETO Y MALLO, Francisco, La ordenación legal de las fundaciones, La Ley, Madrid, 2006, p. 193.

Sin embargo, no ha sido ésta una opinión unánime. Algunos autores discutieron tras la Ley 30/1994 esta medida por ver en ella una limitación de la autonomía del Patronato, privándole de la posibilidad de valorar de forma responsable la conveniencia de aceptar una herencia pura y simplemente o a beneficio de inventario. En este sentido, véase DE PRADA GONZÁLEZ, José María, "Aspectos notariales de la Ley de Fundaciones», Revista Jurídica del Notariado, julio-septiembre 1994, p. 261, al que sigue ORTÍ VALLEJO, Antonio, «Notas sobre la capacidad de las fundaciones", Actualidad civil, número 36, octubre 1998, p. 889, citado este último por MARÍN GARCÍA DE LONARDO, T., «Comentario al artículo 22»..., cit., p. 596.

${ }^{31}$ En este punto, cabe mencionar la RDGRN de 16 de julio de 2007 (LA LEY 95017/2007) cuando afirma respecto de las fundaciones llamadas a una herencia, que la aceptación es siempre a beneficio de inventario, sin que para considerar producidos los efectos del mismo en su favor sea preciso, por tanto, que las llamadas declaren querer utilizar dicho beneficio. 
personas físicas y jurídicas, "las fundaciones y asociaciones declaradas de utilidad pública o de interés social». Por tanto, la normativa catalana, no es que exima de la obligación de tomar inventario, sino que establece que aun cuando se incumpla esta obligación de tomar inventario, única formalidad exigible en este territorio al no requerirse la manifestación expresa al efecto, las fundaciones gozarán de pleno derecho de este beneficio.

$\mathrm{Al}$ margen de este caso específico, la trascendencia que la opción por el beneficio de inventario tiene en cuanto a los acreedores, por la limitación de responsabilidad que conlleva, nos lleva admitir la necesidad de que el Patronato formalice el inventario en tiempo y forma para que la fundación pueda gozar de este beneficio.

Esta opinión la avala precisamente el párrafo segundo del artículo 22.1 de la Ley de Fundaciones, al prever la responsabilidad de los patronos frente a la fundación cuando ésta pierda el beneficio de inventario por haber incurrido aquéllos en alguna de las causas que determinan su pérdida conforme al artículo 1024 del Código Civil. De ello se infiere que si se pierde el beneficio, conforme al número primero del artículo 1024 del Código Civil, por dejar de incluir a sabiendas en el inventario alguno de los bienes, derechos y acciones de la herencia, es porque el heredero tiene obligación de formar responsable y diligentemente el referido inventario ${ }^{32}$.

En consecuencia, los patronos, sin necesidad de declaración al respecto, se entiende que aceptan la herencia a beneficio de inventario, pero para que este recurso produzca a favor del heredero todos los efectos previstos por la ley, aquéllos deberán cumplir las normas y requisitos legales en orden a la formación del inventario y el pago de deudas y legados ${ }^{33}$.

32 En este sentido se manifiestan DE PRADA GONZÁLEZ, J.M., "Aspectos notariales...», cit., p. 261, quien argumenta en contra del beneficio legal de inventario en la aceptación de herencias por las fundaciones que «vedar la posibilidad de adquisición pura y simple supone un perjuicio para las fundaciones, ya que el beneficio de inventario implica una serie de enojosos trámites judiciales que encarece y retarda la libre disposición de los bienes». De esta argumentación, se infiere que el autor entiende que la fundación tiene la obligación de cumplimentar los trámites del inventario, aunque el beneficio venga impuesto por la Ley. De la misma opinión, MARÍN GARCÍA DE LONARDO, T., "Comentario al artículo 22»..., cit., p. 597, quien afirma expresamente que "[e]l que la aceptación de herencias por las fundaciones se entienda hecha a beneficio de inventario no le exime del cumplimiento de las normas legales previstas en el Código civil al respecto».

33 Hay que recordar con SANTOS MORÓN que junto a los supuestos del 1024, existen otros casos previstos en el Código Civil que determinan la pérdida del beneficio de inventario como el supuesto del artículo 1002 y el del artículo 1018, y, en este sentido afirma la autora que, aunque el art. 22.1 no haga referencia expresa a estos supuestos, "deben entenderse igualmente comprendidos en su ámbito, de forma que los patronos responderán de la pérdida del beneficio de inventario derivada de su actuación con independencia de la causa concreta que lo origine». SANTOS MORÓN, M.J., «El patrimonio de la fundación...», cit., p. 329. 
La falta de cumplimiento de estos requisitos y la consiguiente privación de los efectos derivados del beneficio de inventario, conllevaría, asimismo, la responsabilidad de los patronos por el perjuicio causado a la fundación.

La responsabilidad de los patronos viene regulada en el artículo 17 de la Ley 50/2002, en cuyo apartado primero contiene una regla general de actuación diligente de los patronos en el ejercicio de su cargo, previendo en su apartado segundo la responsabilidad solidaria de los patronos frente a la fundación por los daños y perjuicios que causen por actos contrarios a la Ley o a los Estatutos, o por los realizados sin la diligencia con la que deben desempeñar el cargo ${ }^{34}$.

Cabría plantearse qué ocurre en el caso de que los patronos no hayan cumplimentado el beneficio de inventario, incurriendo en alguna de las causas de su pérdida, cuando esta pérdida no implique perjuicio económico real para la fundación por ser el activo hereditario mayor que el pasivo $^{35}$. Entablada la correspondiente acción de responsabilidad, será la autoridad judicial competente quien determine, atendiendo las circunstancias del caso, si los patronos han causado un perjuicio económico a la fundación al incurrir en una causa de pérdida del beneficio de inventario.

Si no existe perjuicio real es probable que no pueda exigirse responsabilidad a los patronos, aunque, según los supuestos, esta ausencia de daños y perjuicios no excluye la actuación negligente de los patronos. Evidentemente, no hay actuación diligente si a sabiendas dejan de incluir en el inventario algún bien de la herencia, ni tampoco si antes de pagar deudas y legados enajenasen bienes de la herencia sin autorización judicial o la de todos los interesados. El incumplimiento del deber general de diligencia de los patronos, previsto en el apartado primero del artículo 17, puede ocasionar asimismo su cese en el cargo, si así se declara en resolución judicial, conforme al artículo 18.2.d) de la Ley ${ }^{36}$.

${ }^{34}$ No obstante, quedarán exentos de responsabilidad quienes hayan votado en contra del acuerdo, y quienes prueben que, no habiendo intervenido en su adopción y ejecución, desconocían su existencia o, conociéndola, hicieron todo lo conveniente para evitar el dańo o, al menos, se opusieron expresamente a aquél (cfr. art. 17.2 in fine).

35 En tal hipótesis, dice SANTOS MORÓN, «no creemos que pueda imputarse responsabilidad a los patronos cuyo comportamiento trae como consecuencia la aceptación pura y simple de la herencia. Al menos, no cabrá imputarles la responsabilidad patrimonial prevista en el artículo 17.2 de la Ley de Fundaciones, puesto que tal responsabilidad presupone la existencia de dańo y en la hipótesis comentada no lo hay». SANTOS MORÓN, M.J., «El patrimonio de la fundación...", cit., p. 328.

36 En este orden de cosas, afirma SANTOS MORÓN, que, a falta de perjuicio económico, «la imposición de esta sanción quizás deba restringirse a los supuestos de pérdida del beneficio de inventario derivados de una actuación claramente ilícita de los patronos, como son los enun- 
Si la pérdida del beneficio de inventario ha causado perjuicio económico y ha tenido lugar por la actuación negligente de los patronos se desencadenarán ambos efectos, responsabilidad y cese.

\section{b) Tramitación Notarial del inVEntario tras La Ley I $5 / 20$ I 5 , DE 2 DE JULIO, DE LA JURISDiCCIÓN VOLUNTARIA}

Supuesta la obligación del Patronato de cumplimentar todos los requisitos de tiempo y forma legalmente previstos para la formación del inventario, no debe olvidarse que tras la entrada en vigor de la Ley 15/2015, de 2 de julio, de la Jurisdicción Voluntaria, la formación del inventario en sede de aceptación de herencia pasa a ser una competencia exclusivamente notarial.

La Ley 15/2015, de 2 de julio, de la Jurisdicción Voluntaria, con la finalidad de atribuir a los Notarios funciones que hasta el momento sólo han correspondido al Juez y que, sin embargo, encajan perfectamente en el ámbito de competencias de aquéllos por ser actos de documentación y autenticación, modifica determinados artículos del Código Civil. Además del artículo 1011 en el que se dispone que "la declaración de hacer uso del beneficio de inventario deberá hacerse ante Notario», se reforman los artículos 1014, 1015, 1017, 1019, 1020, 1024, 1030 y 1033 y se añaden dos nuevos artículos en la Ley del Notariado, el 67 y el 68, que conforman la Sección 6.a del Capítulo III del nuevo Título VII, bajo la rúbrica «De la formación del inventario» ${ }^{37}$.

La formación del inventario es un acto de documentación, con el que se acredita el hecho mismo de su realización, así como que han sido efectuadas las citaciones legalmente previstas. En la escasa utilización de esta figura en la actualidad ha influido de forma decisiva la complejidad y los costes y dilaciones que implicaba su tramitación judicial ${ }^{38}$. Con la nueva regulación se superan las dudas existentes en atención a la posible formación notarial del inventario, que ahora se configura como actuación de competencia notarial exclusiva. De esta forma quizás se revitalice en un futuro la institución.

ciados en los artículos 1002 y 1024 CC. La hipótesis prevista en el artículo 1018 CC, aunque implique una cierta negligencia por parte de los patronos, no parece que merezca sanción tan rigurosa». SANTOS MORÓN, M.J., "El patrimonio de la fundación...», cit., pp. 329-330.

37 Puede verse en cuanto a la regulación del beneficio de inventario en los arts. 67 y $68 \mathrm{de}$ la Ley del Notariado, OBARRIO MORENO, Juan Alfredo, «La regulación del beneficio de inventario en el Código Civil y el Derecho foral espańol», Revista Jurídica del Notariado, núm. 94, abril-junio 2015, pp. 230-234.

38 En este sentido, puede verse NIETO SÁNCHEZ, José, «Competencia notarial en asuntos no contenciosos", Revista Jurídica del Notariado, núm. XI, extraordinario, 2008, pp. 202-203. 
Conforme al artículo 67.2 de la Ley del Notariado, el heredero que solicite la formación de inventario, bien porque ha aceptado la herencia a beneficio de inventario o lo pretende hacer después, bien porque se ha reservado el derecho para deliberar sobre si acepta o repudia, deberá presentar su título de sucesión hereditaria y deberá acreditar al Notario, o bien comprobar éste mediante información del Registro Civil y del Registro General de Actos de Última Voluntad, el fallecimiento del otorgante y la existencia de disposiciones testamentarias. Tal como dice el párrafo primero del mismo artículo 67, la formación del inventario que se regula en este expediente es exclusivamente la de aquel que se solicita a los efectos de aceptar o repudiar la herencia por los llamados a ella, y que el Notario formalizará mediante autorización de un acta en la que irá dejando constancia de las sucesivas diligencias practicadas.

Ahora bien, el heredero no podrá hacer la solicitud al Notario en cualquier tiempo, sino que habrá de respetar los diferentes plazos fijados por la Ley.

Cuando el heredero tenga en su poder la herencia o parte de ella ${ }^{39}$ y quiera hacer uso del beneficio de inventario o del derecho a deliberar, deberá comunicarlo a Notario competente ${ }^{40}$ y solicitarle en el plazo único de treinta días ${ }^{41}$, contados desde el siguiente a aquel en que supo ser tal heredero, la formación de inventario notarial con citación a los acreedores y legatarios para que acudan a presenciarlo si les conviniere.

Cuando, por el contrario, el heredero no tenga en su poder la herencia o parte de ella, ni haya practicado gestión alguna como tal heredero ${ }^{42}$, el plazo de treinta días se contará desde el día siguiente a aquel en que expire el plazo que se le hubiese fijado para aceptar o repudiar la herencia conforme al artículo 1005, o desde el día en que la hubiese aceptado o hubiera gestionado como heredero.

Finalmente, no concurriendo ninguna de las circunstancias vistas, si no se hubiere presentado demanda alguna contra el heredero, podrá éste aceptar a beneficio de inventario o con el derecho de deliberar, mientras no

39 Cfr. art. 1014 Código Civil.

40 Será competente el Notario con residencia en el lugar en que hubiera tenido el causante su último domicilio o residencia habitual, o donde estuviere la mayor parte de su patrimonio, con independencia de su naturaleza de conformidad con la ley aplicable, o en el lugar en que hubiera fallecido, siempre que estuvieran en Espańa, a elección del solicitante. También podrá elegir a un Notario de un Distrito colindante a los anteriores. En defecto de todos ellos, será competente el Notario del lugar del domicilio del requirente.

${ }^{41} \mathrm{El}$ art. 1014 Código Civil, en su anterior redacción, concedía al heredero bien diez días, bien treinta, desde el siguiente a aquel en que supiere ser tal heredero, según residiera en el lugar donde hubiere fallecido el causante de la herencia o residiera fuera.

42 Cfr. art. 1015 Código Civil. 
transcurran treinta años, plazo para la prescripción de la acción para reclamar la herencia ${ }^{43}$.

La cuestión que se nos plantea, de indudable trascendencia práctica, es cómo se le va a acreditar al Notario que el heredero o herederos se encuentran en una u otra situación a fin de que aquél, como instructor del expediente, tenga la convicción de que se están cumpliendo los plazos previstos por la Ley. Ante la dificultad de valorar o apreciar con datos objetivos los diferentes supuestos, el Notario, en principio deberá aceptar las manifestaciones que, bajo su responsabilidad, haga el requirente sobre el momento en que ha conocido su condición de heredero y sobre si se encuentra o no en posesión total o parcial de la herencia. Lo óptimo, no obstante, será que el Notario pueda tener certeza sobre el dies a quo en el que comienza, según los casos, el cómputo del plazo.

El plazo de treinta días es sólo para manifestar al Notario su voluntad de hacer uso del beneficio de inventario y solicitar su formación y la citación de acreedores y legatarios ${ }^{44}$. Pero no es necesario hacer las citaciones ni comenzar el inventario en ese plazo de treinta días.

Una vez aceptado el requerimiento hecho en plazo, el Notario deberá citar, en cualquiera de las formas reglamentariamente previstas ${ }^{45}$, a los acreedores y legatarios para que acudan, si les conviniera, a presenciar el inventario.

Si se ignorase la identidad o domicilio de cualquiera de ellos, conforme al artículo 67.3 de la Ley del Notariado, el Notario dará publicidad del expediente en los tablones de anuncios de los Ayuntamientos correspondientes al último domicilio o residencia habitual del causante, al del lugar del fallecimiento si fuera distinto y donde radiquen la mayor parte de sus bienes, sin perjuicio de la posibilidad de utilizar otros medios adicionales de comunicación además de los anteriores, no en sustitución de los mismos. Los anuncios deberán estar expuestos durante el plazo de un mes ${ }^{46}$.

43 Regla general contenida en el art. 1016 Código Civil.

44 Aunque la nueva redacción del art. 1014 ha suprimido la expresión «a la vez» referida a hacer a un tiempo la petición de formación de inventario y citación a los acreedores y legatarios, lo cierto es que con la nueva redacción, pedir «la formación de inventario notarial con citación a los acreedores y legatarios", entendemos que ambas solicitudes han de hacerse dentro del referido plazo de treinta días.

45 Cfr. art. 202 Reglamento Notarial.

46 A diferencia de la regulación contenida en el Código Civil, el artículo 461-15.5 de la Ley 10/2008, de 10 de julio, del libro cuarto del Código civil de Cataluńa, relativo a las sucesiones, dispone que para tomar el inventario, no es preciso citar a ninguna persona, pero pueden intervenir los acreedores del causante y demás interesados en la herencia. 
Una vez solicitada en plazo la toma del inventario y citados, en su caso, acreedores y legatarios, debe comenzar la formación del mismo.

Conforme al artículo 68.1 de la Ley del Notariado y 1017.1 del Código Civil, el inventario comenzará dentro de los treinta días siguientes a la citación de los acreedores y legatarios. Y deberá concluir dentro de los sesenta días siguientes a contar desde su comienzo. Sin embargo, si por justa causa, se considerase insuficiente el plazo de sesenta días, podrá el Notario prorrogar el mismo hasta el máximo de un año.

Excediéndose de su función propia, el Notario habrá de apreciar la justicia de la causa y decidir de forma discrecional si concede prórroga y por cuánto tiempo, con el límite máximo de un ańo. Por ello, consideramos que hubiera sido más conveniente que el legislador hubiese concedido un plazo general y único, improrrogable, para la solicitud y la formación del inventario, tal como hace en Cataluña la Ley 10/2008, de 10 de julio, del libro cuarto del Código civil de Cataluña, relativo a las sucesiones. Frente a todos estos plazos previstos en el Código Civil, el artículo 461-15.1 de la Ley 10/2008, de 10 de julio, manifiesta de forma clara y concisa que el inventario debe tomarse en el plazo improrrogable de seis meses a contar del momento en que el heredero conoce o puede razonablemente conocer la delación. Se unifican en Derecho catalán el plazo para solicitar la formación de inventario y los plazos para comenzar y finalizar el mismo ${ }^{47}$.

El inventario debe comprender todos los bienes y derechos que integran el activo hereditario, así como también todas las deudas u obligaciones que conformen el pasivo, de modo que resulte completo y quede reflejado en él con exactitud cuál sea el patrimonio del causante ${ }^{48}$.

47 Conforme al artículo 1018 del Código Civil, si por culpa o negligencia del heredero no se principiare o no se concluyere el inventario en los plazos y con las solemnidades prescritas en los artículos anteriores, se entenderá que acepta la herencia pura y simplemente. En el mismo sentido, aunque sin apreciación de culpas, el artículo 461-17 de la Ley 10/2008, de 10 de julio, del libro cuarto del Código civil de Cataluña, relativo a las sucesiones, dispone que si el heredero no toma el inventario en el tiempo y la forma establecidos, se entiende que acepta la herencia de forma pura y simple.

48 Para la formación del inventario, el heredero habrá de proporcionarle al Notario los datos necesarios a fin de que todos los bienes, derechos y deudas de la herencia queden perfectamente identificados. No obstante, aunque la obligación de facilitar los datos necesarios para la formación del inventario la tiene el heredero, entendemos que el Notario también podrá colaborar con el heredero para la obtención de la documentación precisa, accediendo a las bases del Catastro o solicitando del Registro de la Propiedad las certificaciones pertinentes. A este respecto, en relación con los bienes inmuebles inscritos en el Registro de la Propiedad, dice el artículo 68.2 de la Ley del Notariado que se aportarán o se obtendrán por el Notario certificaciones de dominio y cargas. 
Terminado el inventario, se cerrará y protocolizará el acta, debiéndose poner, ésta, en conocimiento del heredero requirente.

Si manifiesta que renuncia a la herencia, conforme al artículo 1022 del Código Civil, el inventario hecho por el heredero aprovechará a los sustitutos y a los herederos abintestato, respecto de los cuales los treinta días para deliberar y para hacer la manifestación que previene el artículo 1.019 se contarán desde el siguiente a aquel en que tuvieren conocimiento de la repudiación.

En el caso de que acepte la herencia a beneficio de inventario, el heredero, o cualquier otra persona designada al efecto, asumirá la administración transitoria del caudal hereditario y procederá a su liquidación pagando a los acreedores y haciendo entrega de los legados ${ }^{49}$ conforme a los artículos 1025 a 1029 del Código Civil ${ }^{50}$.

\section{La aceptación de legados con cargas}

La sucesión mortis causa puede operar bien a título universal, llamando a una persona como heredero, bien a título singular, cuando el llamamiento se le hace como legatario. Es perfectamente posible, por tanto, que una fundación sea nombrada legataria en un testamento. Para el caso de que el legado que se ordene sea un legado con cargas, de las que, conforme al artículo 858 del Código Civil, no estará obligada a responder la fundación, si llegare a aceptarla, sino hasta donde alcance el valor del legado, el artículo 22 de la Ley de Fundaciones establece como requisito de control una comunicación al Protectorado, al igual que se prevé para el caso de la

49 Conforme al art. 1025 Código Civil, los legatarios no podrán demandar el pago de sus legados durante la formación del inventario y el término para deliberar.

${ }^{50}$ En palabras de ROCA-SASTRE MUNCUNILL,»[s]e trata de una verdadera administración, que comporta funciones, facultades y deberes de conservación y defensa de los bienes, pero siempre con la finalidad fundamental de liquidación patrimonial». ROCA-SASTRE MUNCUNILL, L., Derecho..., Tomo III, cit., p. 508.

El Código Civil regula esta materia en los arts. 1025 a 1033. En el art. 1028 prevé cómo resolver la prelación entre los créditos existentes y en el art. 1029 contempla la posibilidad de que concurran acreedores después de pagados los legados en cuyo caso sólo podrán reclamar contra los legatarios en el caso de no quedar en la herencia bienes suficientes para pagarles. Finalmente, cfr. art. 1033 Código Civil, los gastos del inventario y las demás actuaciones a que dé lugar la administración de la herencia aceptada a beneficio de inventario y la defensa de sus derechos, serán de cargo de la misma herencia. A excepción de aquellos gastos imputables al heredero que hubiese sido condenado personalmente por su dolo o mala fe. Lo mismo se entenderá respecto de los gastos causados para hacer uso del derecho de deliberar, si el heredero repudia la herencia. 
repudiación, en el plazo máximo de diez días hábiles siguientes ${ }^{51}$, pudiendo éste ejercer las acciones de responsabilidad que correspondan contra los patronos, si los actos del Patronato fueran lesivos para la fundación.

De este modo, se flexibiliza, en cierto modo, el criterio mantenido tanto por la Ley de Fundaciones del 94, que en el párrafo segundo de su artículo 20 disponía: "[l]a aceptación de legados o donaciones con cargas que puedan desnaturalizar el fin fundacional requerirá la previa autorización del Protectorado ${ }^{52}$ ", como por algunas de las leyes autonómicas, como la de Canarias o Castilla León ${ }^{53}$. Se sigue, sin embargo, la línea marcada en su día por la Ley Vasca de Fundaciones que, en su artículo 21, dispone que "[l]os representantes de la fundación podrán aceptar o repudiar herencias, legados o donaciones siempre que lo consideren conveniente para la fundación, pero deberán ponerlo en conocimiento del Protectorado, que podrá ejercer judicialmente las acciones de responsabilidad procedentes frente a los miembros del órgano de gobierno, cuando de su actuación se derive algún perjuicio para aquélla». Criterio este último que también ha sido asumido por la normativa autonómica posterior, así en Andalucía, Valencia o La Rioja ${ }^{54}$.

51 En opinión de SANTOS MORÓN, llama la atención que no se haya establecido un plazo de 30 días, análogo al previsto en el artículo 21.3 de la Ley de Fundaciones para la comunicación al Protectorado de los actos de disposición sobre los bienes en dicho artículo relacionados; y entiende que quizás la justificación pueda encontrarse en que «la posibilidad de que la fundación aceptara legados o donaciones con cargas se planteó como una hipótesis aislada mientras que la realización de actos de disposición sobre bienes inmuebles, establecimientos mercantiles o industriales, etc., no pertenecientes a la dotación, se consideró una hipótesis más frecuente. De ahí que pretendiera agilizarse la tramitación de las comunicaciones relativas a tales actos de disposición permitiendo la acumulación de varias de ellas mediante la ampliación del plazo preceptivo». SANTOS MORÓN, M.J., «El patrimonio de la fundación...», cit., p. 332.

52 Nos recuerda SANTOS MORÓN que la interpretación de este inciso referente a la desnaturalización del fin fundacional «ocasionó múltiples dudas, por lo que su supresión merece una valoración positiva. Se evitan los problemas anteriormente planteados en torno a si era necesaria la actuación del Protectorado frente a toda liberalidad modal o sólo frente a aquellas que pudieran desvirtuar el fin fundacional». SANTOS MORÓN, M.J., «El patrimonio de la fundación...", cit., p. 330.

53 Cfr. art. 20 Ley 13/2002, de 15 de julio, de Fundaciones de Castilla y León y art. 14 Ley 2/1998, de 6 de abril, de Fundaciones Canarias.

54 La Ley 10/2005, de 31 de mayo de Fundaciones de la Comunidad Autónoma de Andalucía, en su artículo 29 y Ley 1/2007, de 12 de febrero, de Fundaciones de la Comunidad Autónoma de La Rioja, en su artículo 28, establecen un texto igual al de la Ley Estatal exigiendo la comunicación posterior al Protectorado; por su parte, el art. 22.6 de la Ley 8/1998, de 9 de diciembre, de fundaciones de la Comunidad Valenciana, según redacción dada por la Ley 9/2008, 3 julio, de la Generalitat, se remite expresamente al art. 22.2 de la Ley 50/2002. 
Por tanto, los Patronos deberán valorar si aceptan o no los legados con cargas que se dejen a la fundación y si deciden aceptarlos deberán entonces en todo caso ponerlo en conocimiento del Protectorado para que éste pueda ejercer las acciones de responsabilidad pertinentes contra el Patronato si su actuación resultare lesiva para la fundación.

\section{La repudiación de la herencia: formalidades y requisitos complementarios de control}

La repudiación de la herencia es aquella declaración de voluntad en virtud de la cual el heredero manifiesta su intención de no adir la herencia a la que ha sido llamado. Aunque en sus más remotos precedentes, tanto en Derecho romano como en el Derecho español más antiguo, se admitía la repudiación tácita de la herencia, nuestro ordenamiento jurídico la configura como un acto formal que debe hacerse, por tanto, de forma expresa ${ }^{55}$ y en el que la forma pública tiene el carácter ad solemnitatem, de modo que constituye un requisito para su existencia y validez.

$\mathrm{El}$ artículo $1280.4^{\circ}$ del Código Civil prevé que deberán constar en documento público «la repudiación y renuncia de los derechos hereditarios». Con un régimen más riguroso por exigir la forma pública ad solemnitatem y no ad probationem como el precepto anterior, afirmaba el artículo 1008 del mismo Código, hasta la entrada en vigor de la Ley 15/2015, de 2 de julio, de la Jurisdicción Voluntaria, que «[l]a repudiación de la herencia deberá hacerse en instrumento público o auténtico, o por escrito presentado ante el Juez competente para conocer de la testamentaría o del abintestato ${ }^{56}$.

55 A este respecto puede verse ROCA-SASTRE MUNCUNILL cuando afirma que « $[\mathrm{t}]$ anto en Derecho romano [como] en las Partidas era posible la repudiación tácita de la herencia. Pero, a partir del Derecho consuetudinario francés se exige que sea expresa y formal, notarial o judicial (...) para dar seguridad, certeza, seriedad y claridad al acto de repudiación». El Proyecto de Código Civil de 1851 preveía la forma exclusivamente notarial y en la redacción de 1889 se admitía tanto la notarial como la judicial. ROCA-SASTRE MUNCUNILL, L., Derecho..., Tomo III, cit., pp. 493-495. En el mismo sentido CASTÁN, quien además añade que "[1]a razón de exigirse por el Código la forma expresa para la repudiación es (...) la de que el supuesto normal de la sucesión es la aceptación, y es conveniente la autenticidad de la renuncia, ya que ésta interesa a los acreedores y al orden público, puesto que abre paso a otros herederos». CASTÁN TOBEÑAS, J., Derecho civil español..., Tomo VI, Vol. I, cit., p. 178.

56 Desde la promulgación de la Ley de Enjuiciamiento Civil 1/2000, de 7 de enero, los juicios sobre testamentarías y abintestatos han desaparecido como juicios con tipificación procesal propia dentro de la división que la Ley hace de los juicios declarativos, entre juicios ordinarios y juicios verbales, de manera que su inclusión en uno u otro dependerá de la cuantía, tal como disponen los art. 249.2 y 250.2 de la Ley procesal. 
En el mismo sentido, el artículo 461-6.1 de la Ley 10/2008, de 10 de julio, del libro cuarto del Código civil de Cataluña, relativo a las sucesiones, dispone que «[l]a repudiación de la herencia debe hacerse de forma expresa en documento público o mediante escrito dirigido al Juez competente». En términos prácticamente idénticos, se manifiesta el artículo 351 del Decreto Legislativo 1/2011, de 22 de marzo, del Gobierno de Aragón, por el que se aprueba, con el título de «Código del Derecho Foral de Aragón», el Texto Refundido de las Leyes civiles aragonesas, cuando afirma que "[l]a repudiación de la herencia ha de hacerse de forma expresa en escritura pública o mediante escrito dirigido al Juez competente».

Nos encontramos ante un acto de documentación de una voluntad, asumible por el Notariado por tratarse de su función propia, en el que la forma pública que se exige es requisito para la validez y eficacia de la declaración ${ }^{57}$.

Hasta la entrada en vigor de la Ley de la Jurisdicción Voluntaria esta forma, como hemos visto, podía ser bien judicial bien notarial.

Desde el día 23 de julio de 2015, la repudiación de la herencia, conforme al artículo 1008 del Código Civil, que ha recibido nueva redacción por la Disposición final primera de la Ley 15/2015, deberá hacerse siempre en instrumento público ante Notario competente, conforme a las reglas generales de competencia notarial. Ello no obsta, entendemos, para que en el seno de un procedimiento de división judicial de la herencia, se documente judicialmente la renuncia de uno de los herederos parte en el procedimiento ${ }^{58}$.

Las fundaciones llamadas a una herencia podrán a través del Patronato bien aceptarla a beneficio de inventario, bien repudiarla en la forma exami-

57 Han sido muchos los autores que expresan con rotundidad cómo la forma en la repudiación hereditaria constituye un requisito constitutivo. LACRUZ BERDEJO, José Luis, Elementos de Derecho civil, Derecho de Sucesiones, Tomo V, 4a edición, Madrid, Dykinson, 2009, p. 78 y CASTÁN TOBEÑAS, J., Derecho civil español..., Tomo VI, Vol.I, cit., p. 177. Más recientemente, puede verse GETE-ALONSO Y CALERA, Ma del Carmen, «Adquisición de la herencia», Tratado de derecho de sucesiones: Código civil y normativa civil autonómica: Aragón, Baleares, Cataluña, Galicia, Navarra, País Vasco, coordinado por Judith Solé Resina; María del Carmen Gete-Alonso y Calera (dir.), tomo. 1, Cizur Menor, Navarra, Civitas Thomson Reuters, 2011, p. 313.

58 Surge la duda de si en Cataluña y Aragón podrá seguir formalizándose la renuncia hereditaria en sede judicial, tal como se reconoce en su legislación específica, por los cauces del procedimiento general de la Jurisdicción Voluntaria regulado en la Ley 15/2015, de 2 de julio. Si nos ajustamos al tenor literal de los artículos 461-6.1 de la Ley 10/2008, de 10 de julio, y 351 del Decreto Legislativo 1/2011, de 22 de marzo, del Gobierno de Aragón, es posible, aunque en la práctica entendemos que la renuncia en sede judicial irá dejando paso a la forma notarial de la misma, no sólo por la incompetencia de los Tribunales en vista de la regulación contenida en la Ley de la Jurisdicción Voluntaria, sino también por la agilidad y rapidez de la actuación del Notario y la propia naturaleza notarial del acto, como documentador de una declaración de voluntad. 
nada. La capacidad para repudiar una herencia es por tanto la misma que para aceptarla. Las diferencias radican tanto en las formalidades requeridas al efecto como en los requisitos complementarios de control establecidos en el artículo 22.2 de la Ley de Fundaciones 50/2002, que expresamente dispone que la renuncia «será comunicada por el Patronato al Protectorado en el plazo máximo de los diez días hábiles siguientes, pudiendo éste ejercer las acciones de responsabilidad que correspondan contra los patronos, si los actos del Patronato fueran lesivos para la fundación, en los términos previstos en el esta Ley».

Lo cierto es que los requisitos o controles exigidos por la normativa específica de fundaciones en cuanto a la renuncia hereditaria han evolucionado, como en el caso de la aceptación de los legados con cargas, de más a menos, desde el artículo 993 del Código Civil hasta el vigente artículo 22.2 de la Ley 50/2002.

Como sabemos, el mencionado precepto del Código Civil exige para la validez de la repudiación la aprobación judicial con audiencia del Ministerio Público. El artículo 20 de la anterior Ley 30/1994, de Fundaciones e Incentivos fiscales, en esa dirección de mantener mecanismos de control a ciertas actuaciones llevadas a cabo por las fundaciones, introdujo, no obstante, una importante modificación al exigir, de forma alternativa, para repudiar herencias o legados, bien la previa autorización del Protectorado bien, en defecto de ésta, la aprobación judicial con audiencia del Ministerio Público ${ }^{59}$. Finalmente, el artículo 22 de la vigente Ley de Fundaciones, flexibilizando aún más el sistema, en la línea proclamada por su Exposición de Motivos de potenciar la autonomía de gestión de las fundaciones y limitar la intervención administrativa al respecto, suprime la intervención judicial y establece como único requisito complementario de control, no la autorización previa, sino uno menos riguroso, como es la posterior comunicación por el Patronato al Protectorado en los términos vistos ${ }^{60}$. Esta

59 En relación con lo previsto en el art. 20.3 de la Ley 30/1994, ya afirmó DE PRADA GONZÁLEZ en su momento que «una vez más se carga a las fundaciones de requisitos perturbadores para su funcionamiento con clara desconfianza en el Patronato que gozó, en cambio, de la confianza del fundador». DE PRADA GONZÁLEZ, J.M., "Aspectos notariales...", cit., p. 262.

${ }^{60}$ En este sentido opina MARÍN GARCÍA DE LONARDO que «la Ley de Fundaciones ha venido a modificar el criterio del Código civil evitando (...) los retrasos y la falta de agilidad que se producirían como consecuencia de la necesidad de acudir a la vía judicial», optándose por dar «la misma solución a la repudiación que a los actos de disposición del párrafo 3 del art. 21 de la Ley de Fundaciones (actos de disposición de aquellos bienes y derechos fundacionales distintos de los que forman parte de la dotación o estén vinculados directamente al cumplimiento de los fines fundacionales), en la medida en que la capacidad para renunciar está relacionada con la capacidad para disponer». MARÍN GARCÍA DE LONARDO, T., "Comentario al artículo 22»..., cit., pp. 606-607. 
misma línea ha sido seguida por una parte de la normativa autonómica de fundaciones, como la de Galicia, Andalucía y Valencia ${ }^{61}$. Sin embargo, otras normas anteriores al año 2002 siguen manteniendo el criterio de la anterior Ley de 1994 y exigen bien la autorización del Protectorado ${ }^{62}$, bien esta autorización o de forma alternativa, como hacía el artículo 20 de aquella norma, la aprobación judicial con audiencia del Ministerio Público ${ }^{63}$. No obstante, teniendo en cuenta el título competencial del artículo 22.2, para aquellas Comunidades Autónomas sin competencia en materia civil, debe entenderse aplicable en este punto la legislación estatal ${ }^{64}$.

Resulta incuestionable, como reconoció el Tribunal Constitucional en su Sentencia 341/2005, de 21 de diciembre ${ }^{65}$, que «del rasgo básico que supone el que las fundaciones tengan un fin de interés general se deriva la exigencia de la intervención administrativa». Y precisamente las atribuciones a los poderes públicos encuentran su razón de ser en «la necesidad de proveer a la Administración de los instrumentos necesarios para asegurar que las fundaciones no se desvían de los fines de interés público que según el Código Civil (art. 35.1) les son propios».

Sin embargo, la Exposición de Motivos de la Ley 50/2002 pone de manifiesto cómo uno de los objetivos prioritarios de Ley pasaba por reducir considerablemente la intervención de los poderes públicos en la actuación de las fundaciones. La Ley de Fundaciones 50/2002, aboga, pues, por una mayor autonomía y libertad de los Patronos que conlleva, no obstante, su responsabilidad en caso de que su actuación sea lesiva para la fundación.

${ }^{61} \mathrm{El}$ art. 30 Ley 12/2006, de 1 de diciembre, de fundaciones de interés gallego, y el art. 29 Ley 10/2005, de 31 de mayo de Fundaciones de la Comunidad Autónoma de Andalucía reproducen el texto del artículo 22 de la Ley de Fundaciones. Por su parte, el art. 22.6 Ley 8/1998 de 9 de diciembre, de fundaciones de la Comunidad Valenciana, modificada por la ley 9/2008, 3 julio, de la Generalitat, se remite al referido artículo 22.2.

62 Cfr. art. 20 Ley 13/2002, de 15 de julio, de Fundaciones de Castilla y León y art. 28 Ley 1/2007, de 12 de febrero, de Fundaciones de la Comunidad Autónoma de La Rioja.

${ }^{63}$ Cfr. art. 17.1 y 2 Ley 1/1998, de 2 de marzo, de Fundaciones de la Comunidad de Madrid y art. 14.3 Ley 2/1998, de 6 de abril, de Fundaciones Canarias.

En este punto cabe recordar que el inciso último del artículo 17.2 de la Ley de Fundaciones de la Comunidad de Madrid en lo referente a la aprobación judicial posterior con audiencia del Ministerio Público ha sido declarado inconstitucional en STC 341/2005, de 21 de diciembre, (LA LEY 160/2006) al incurrir en extralimitación competencial por entender el Alto Tribunal que «la correcta previsión de una intervención judicial, con audiencia del Ministerio Fiscal, por mucho que responda a intereses jurídico-públicos, supone la articulación de un cauce procesal cuyo establecimiento es competencia exclusiva del Estado ex art. 149.1.6 CE».

${ }^{64}$ De esta opinión, SANTOS MORÓN, M.J., "El patrimonio de la fundación...», cit., pp. 335-336.

65 Tribunal Constitucional, Pleno, Sentencia 341/2005 de 21 Dic. 2005, Rec. 2544/1998, Ponente Elisa Pérez Vera (LA LEY 160/2006). 
En este intento de minimizar la intervención pública, se ha sustituido en la mayor parte de los casos la exigencia de autorización previa de actos y negocios jurídicos por parte del Protectorado, por la simple comunicación al mismo del acto o negocio realizado, pero sin obviar que el control debe subsistir en aquellos supuestos en que pueda tener lugar un deterioro o merma del patrimonio de la fundación con el consiguiente quebranto de los fines fundacionales ${ }^{66}$. El Protectorado deberá valorar si la repudiación de la herencia ha supuesto una pérdida o perjuicio patrimonial para la fundación, en cuyo caso exigirá la responsabilidad correspondiente a los patronos, quienes, tal como se prevé en el artículo 17.2, responderán solidariamente frente a la fundación de los daños y perjuicios que causen por actos contrarios a la Ley o a los Estatutos, o por los realizados sin la diligencia con la que deben desempeñar el cargo.

La obligación de comunicar determinados actos al Protectorado para que éste pueda ejercer las acciones de responsabilidad que correspondan contra los patronos, como en la repudiación de la herencia y la aceptación de legados con cargas, queda enmarcada dentro de la función más general de control que se le encomienda al Protectorado en el artículo 35 de la Ley $50 / 2002$, conforme al cual éste debe "velar por el efectivo cumplimiento de los fines fundacionales, de acuerdo con la voluntad del fundador, y teniendo en cuenta la consecución del interés general», así como "verificar si los recursos económicos de la fundación han sido aplicados a los fines fundacionales, pudiendo solicitar del Patronato la información que a tal efecto resulte necesaria, previo informe pericial realizado en las condiciones que reglamentariamente se determine».

En este punto, la doctrina de forma mayoritaria ha venido entendiendo que el artículo 993 del Código Civil, modificado por el artículo 20 de la Ley

${ }^{66}$ En palabras de la Exposición de motivos: «Hasta el momento, esta previsión constitucional [art. $34 \mathrm{CE}$ ] se encontraba cumplida mediante la Ley 30/1994, de 24 de noviembre, de Fundaciones y de incentivos fiscales a la participación privada en actividades de interés general, que regulaba en un solo cuerpo legal el régimen jurídico de los entes fundacionales y las ventajas de carácter impositivo que se conceden a las personas privadas, físicas o jurídicas (sin limitarse a las de naturaleza fundacional), por sus actividades o aportaciones económicas en apoyo de determinadas finalidades de interés público o social. Dicha Ley puso fin a un régimen regulador de las fundaciones que cabría calificar de vetusto (algunas de sus normas databan de mediados del siglo xIx), fragmentario, incompleto y aun contradictorio, satisfaciendo las legítimas demandas y aspiraciones reiteradamente planteadas por el sector (...)». Y en este sentido, sigue diciendo, «la reforma da respuesta a las demandas de las propias fundaciones, en un sentido general de superar ciertas rigideces de la anterior regulación, que, sin significar claras ventajas para el interés público, dificultaban el adecuado desenvolvimiento de la actividad fundacional: simplificación de trámites administrativos, reducción de los actos de control del Protectorado, reforma del régimen de organización y funcionamiento del Patronato, etc». (BOE-A-2002-25180) Puede consultarse en https://www.boe.es 
30/199467, había quedado finalmente derogado de forma tácita en su último inciso por la Ley de Fundaciones 50/2002, por lo que debía entenderse suprimida la exigencia de la posterior aprobación judicial de la repudiación ${ }^{68}$.

Aceptada esta situación, nos encontramos con la reciente realidad legislativa contenida en la Ley 15/2015, de 2 de julio, de la Jurisdicción Voluntaria, que en su artículo 93 regula los supuestos que en sede de aceptación y repudiación de herencias requieren la intervención judicial. Y, a este efecto, olvidando lo que tanto la Ley estatal de Fundaciones como las Leyes autonómicas más recientes disponen, insiste en la regulación del artículo 993 del Código Civil, y dispone expresamente en su apartado 3 que "[a]simismo, será necesaria la aprobación judicial para la eficacia de la repudiación de la herencia realizada por los legitimos representantes de las asociaciones, corporaciones y fundaciones capaces de adquirir».

En consecuencia, al ser considerada la intervención judicial en la repudiación de las herencias por las fundaciones una materia reservada en exclusiva a la legislación estatal, ex art. 149.1.6 de la Constitución Española, tal como reconoce el Tribunal Constitucional en la referida Sentencia 341/2005 de 21 diciembre, podría afirmarse que el legislador estatal ha desarrollado esta competencia en la nueva Ley de Jurisdicción Voluntaria, ratificando la exigencia contenida en el artículo 993 del Código Civil y que será de aplicación general en toda Espańa.

La práctica de los Tribunales nos pondrá de manifiesto la efectiva aplicación o no de esta anterior exigencia ahora revitalizada por la Ley de Jurisdicción Voluntaria ${ }^{69}$.

67 De esta opinión es COBO GÁLVEZ cuando afirma que el artículo 20 de la ley 30/1994 modifica el citado artículo del Código Civil «al introducir para las fundaciones la posibilidad de la repudiación con la previa autorización del protectorado». COBO GÁLVEZ, P., "Comentario al artículo $20 \ldots »$, cit., p. 173.

68 En este sentido, entiende SANTOS MORÓN que «tras la publicación de la nueva Ley de Fundaciones el inciso final del artículo 993 CC, en cuanto requiere la aprobación judicial para la repudiación de la herencia por parte de las fundaciones, debe considerarse definitivamente derogado». SANTOS MORÓN, M.J., «El patrimonio de la fundación...», cit., p. 335. De forma idéntica, LÓPEZ NIETO Y MALLO, F., La ordenación legal..., cit., p. 206.

GETE-ALONSO sin embargo es de la opinión contraria y entiende como requisito adicional para la repudiación el previsto por el artículo 993 Código Civil, esto es, para esta autora no es discutible que la eficacia de la repudiación requiere aprobación judicial con audiencia del Ministerio Fiscal. GETE-ALONSO Y CALERA, M.C., «Comentario al artículo 993»..., cit., p. 1489.

69 No obstante, no conviene olvidar, como pone de manifiesto GONZÁLEZ POVEDA, Bienvenido, La Jurisdicción Voluntaria. Doctrina y formularios, 4a edición actualizada por Pedro González Poveda y Jorge González Rodríguez, Cizur-Menor (Navarra), Thomson-Aranzadi, 2008 , p. 1309, que se omiten en su obra «los formularios de este procedimiento por su escasísima posibilidad de aplicación práctica. No tenemos noticia de haber sido utilizados». 


\section{Bibliografía}

Castán Tobeñas, José, Derecho civil español, común y foral. Derecho de sucesiones. La sucesión en general. La sucesión testamentaria (1. ${ }^{a}$ parte), Tomo VI, Vol.I, 9. ${ }^{a}$ edición, Madrid, Reus, 1989.

Cobo Gálvez, Pablo. "Comentario al artículo 20 de la Ley de Fundaciones», en Comentarios a la Ley de Fundaciones e Incentivos Fiscales, Madrid, Marcial Pons, 1995, pp. 170-173.

De Prada González, José María, «Aspectos notariales de la Ley de Fundaciones», Revista Jurídica del Notariado, julio-septiembre 1994, pp. 203-282.

Gete-Alonso y Calera, M. ${ }^{a}$ del Carmen, "Adquisición de la herencia», Tratado de derecho de sucesiones: Código civil y normativa civil autonómica: Aragón, Baleares, Cataluña, Galicia, Navarra, País Vasco, coordinado por Judith Solé Resina; María del Carmen Gete-Alonso y Calera (dir.), Tomo. 1, Cizur Menor, Navarra, Civitas Thomson Reuters, 2011, pp. 275-324.

Gete-Alonso y Calera, M. a del Carmen, «Comentario al artículo 993», Código Civil comentado, Vol. II, Libro III, De los diferentes modos de adquirir la propiedad (artículos 609 a 1087), Cizur Menor, Navarra, Civitas Thomson Reuters, 2011, pp. 1487-1490.

Gete-Alonso y Calera, M. ${ }^{\text {a }}$ del Carmen, "Responsabilidad hereditaria», Tratado de derecho de sucesiones: Código civil y normativa civil autonómica: Aragón, Baleares, Cataluña, Galicia, Navarra, País Vasco, coordinado por Judith Solé Resina; María del Carmen Gete-Alonso y Calera (dir.), Tomo. 1, Cizur Menor, Navarra, Civitas Thomson Reuters, 2011, pp. 325-373.

González Cueto, Tomás, Comentarios a la Ley de Fundaciones: Ley 50/2002, de 26 de diciembre, Cizur Menor, Navarra, Aranzadi, 2003.

González Poveda, Bienvenido, La Jurisdicción Voluntaria. Doctrina y formularios, 4. ${ }^{a}$ edición actualizada por Pedro González Poveda y Jorge González Rodríguez, Cizur-Menor (Navarra), Thomson-Aranzadi, 2008.

Irurzun Goicoa, Domingo, "Función del acta de notoriedad en el abintestato (Comentario a la inquietante Resolución de 19 de junio de 2013)», Revista Jurídica del Notariado, núm. 85, enero-marzo 2013, pp. 71-96.

Lacruz Berdejo, José Luis, Tratado teórico práctico de Derecho Civil, Derecho de Sucesiones, Parte General, Tomo V, Vol. 1., Barcelona, Bosch, 1961.

Lacruz Berdejo, José Luis, Elementos de Derecho civil, Derecho de Sucesiones, Tomo $\mathrm{V}$, 4. $^{\mathrm{a}}$ edición, Madrid, Dykinson, 2009.

López Nieto y Mallo, Francisco, La ordenación legal de las fundaciones, La Ley, Madrid, 2006.

Marín García De Lonardo, Teresa, "Comentario al artículo 22», Comentarios a la Ley de Fundaciones, coor. Jesús Olavarría Iglesia, Valencia, Tirant lo Blanch, 2008, pp. 593-608.

Nieto Sánchez, José, "Competencia notarial en asuntos no contenciosos», Revista Juridica del Notariado, núm. XI, extraordinario, 2008, pp. 71-230. 
Rivas Martínez, Juan José, Derecho de sucesiones: común y foral, Tomo III, $4 .^{\mathrm{a}}$ edición, Madrid, Dykinson, 2009

Roca-Sastre Muncunill, Luis, Derecho de Sucesiones, Tomo III, 1. ${ }^{a}$ edición, Barcelona, Editorial Bosch, 1994.

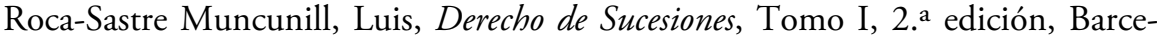
lona, Editorial Bosch, 1995.

Santos Morón, María José, «El patrimonio de la fundación. Régimen de gestión patrimonial» (arts. 19 a 22 y 28), en Comentarios a las leyes de Fundaciones y de Mecenazgo (directores Santiago Muñoz Machado, Miguel Cruz Amorós y Rafael de Lorenzo García), Fundación ONCE, Madrid, Iustel, 2005, pp. 327337.

Obarrio Moreno, Juan Alfredo, «La regulación del beneficio de inventario en el Código Civil y el Derecho foral español», Revista Jurídica del Notariado, núm. 94, abril-junio 2015, pp. 230-234. 